\title{
LIG3 Gene
}

National Cancer Institute

\section{Source}

National Cancer Institute. LIG3 Gene. NCI Thesaurus. Code C116584.

This gene is involved in DNA double-strand break repair. 